\title{
Patriarch Tarasios: An exponent of Byzantine church diplomacy in relation to Rome and the bishop of Constantinople
}

\begin{tabular}{|c|c|}
\hline \multicolumn{2}{|c|}{$\begin{array}{l}\text { Author: } \\
\text { Chifar Nicolae }\end{array}$} \\
\hline \multicolumn{2}{|c|}{$\begin{array}{l}\text { Affiliations: } \\
\text { }{ }^{2} \text { Department of Religion, } \\
\text { Faculty of Theology, } \\
\text { University Andrei Saguna, } \\
\text { Sibiu, Romania }\end{array}$} \\
\hline \multicolumn{2}{|c|}{$\begin{array}{l}{ }^{2} \text { Department of Systematic } \\
\text { and Historical Theology, } \\
\text { Faculty of Theology and } \\
\text { Religion, University of } \\
\text { Pretoria, Pretoria, } \\
\text { South Africa }\end{array}$} \\
\hline \multicolumn{2}{|c|}{$\begin{array}{l}\text { Research Project Registration: } \\
\text { Project Leader: J. Pillay @ } \\
\text { Project Number: } 04653484\end{array}$} \\
\hline \multicolumn{2}{|c|}{$\begin{array}{l}\text { The author is participating as } \\
\text { the research associate of } \\
\text { Dean Prof. Dr Jerry Pillay, } \\
\text { Faculty of Theology and } \\
\text { Religion, University of } \\
\text { Pretoria. }\end{array}$} \\
\hline \multicolumn{2}{|c|}{$\begin{array}{l}\text { Corresponding author: } \\
\text { Chifar Nicolae, } \\
\text { nicolae.chifar@ulbsibiu.ro }\end{array}$} \\
\hline $\begin{array}{l}\text { Dates: } \\
\text { Received: } 04 \\
\text { Accepted: } 23 \\
\text { Published: } 30\end{array}$ & $\begin{array}{l}\text { upr. } 2021 \\
\text { uly } 2021 \\
\text { Sept. } 2021\end{array}$ \\
\hline \multicolumn{2}{|c|}{$\begin{array}{l}\text { How to cite this article: } \\
\text { Nicolae, C., 2021, 'Patriarch } \\
\text { Tarasios: An exponent of } \\
\text { Byzantine church diplomacy } \\
\text { in relation to Rome and the } \\
\text { bishop of Constantinople', } \\
\text { HTS Teologiese Studies/ } \\
\text { Theological Studies } \\
77(4), \text { a6691. https://doi. } \\
\text { org/10.4102/hts.v77i4.6691 }\end{array}$} \\
\hline \multicolumn{2}{|c|}{$\begin{array}{l}\text { Licensee: AOSIS. This work } \\
\text { is licensed under the } \\
\text { Creative Commons } \\
\text { Attribution License. }\end{array}$} \\
\hline \multicolumn{2}{|l|}{ Read online: } \\
\hline 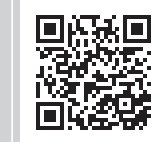 & $\begin{array}{l}\text { Scan this QR } \\
\text { code with your } \\
\text { smart phone or } \\
\text { mobile device } \\
\text { to read online. }\end{array}$ \\
\hline
\end{tabular}

On September 24, 787, the works of the VII Ecumenical Synod were opened in the 'Saint Sophia' Church in Nicaea, after the first attempt, on August 7, 786, had failed. Although the nominal presidency was held by the legates of Pope Adrian I, the effective presidency was exercised by Patriarch Tarasios of Constantinople. A skilful church diplomat, with experience, gained as an imperial secretary and a remarkable theologian whose authority was imposed even during his election as a patriarch amongst the laity, Tarasios meticulously and clairvoyantly prepared for the deployment of the Nicene synod. This is noticeable from the agreement made with the papal legates regarding the reading of the letters of Pope Adrian I whose content directly concerned the persona of the patriarch, agreeing to omit those compromising paragraphs, from the procedure of re-welcoming in the communion of the church of some former iconoclastic bishops, by correctly managing the resistance of the monks to whom he gave satisfaction regarding the patristic and traditional argumentation of the cult of the holy icons and by rejecting point-by-point the dogmatic decision of the iconoclastic synod of Hieria (754), a rejection of which the patriarch Tarasie is in all probability the author. Satisfied with the success of the synod, whose craftsman he indeed was, Patriarch Tarasios was able to communicate to both Pope Adrian I and the emperors and clergy of Constantinople that the unity of the Church residing in Christ had been restored and that the place in the church and due honour of the holy icons had been restored through the synodal decision of 302 participants. The success of the Seventh Ecumenical Council is unequivocally because of the tactful and competent preparation and management of Patriarch Tarasios.

Contribution: The perspective we promote on the events highlighted in the study, could contribute to unblocking the theological dialogue between Orthodox and Catholics on the issue of papal primacy, the study thus promotes HTS as an important forum for mediating interfaith dialogue.

Keywords: VII Ecumenical Synod; Patriarch Tarasios; Rome; Eastern patriarchs; church diplomacy; iconoclasm; the cult of holy icons.

\section{Introduction}

The recognition of the election of Tarasios as patriarch amongst the laity provoked a dissatisfactory response from Rome, which conditioned this election on the rehabilitation of the cult of icons through an ecumenical synod. The requirements stipulated by Pope Adrian I in the letters sent to the imperial court and to the patriarch, as well as in the instructions given to the papal legates, revealed some claims to the supremacy of the Roman throne. Through a skilful church diplomacy, Tarasios managed to coordinate the work of the Seventh Ecumenical Council (787) in such a way as to give satisfaction to not only the papal legates but also to consolidate his position both in front of the Constantinople episcopate, almost entirely adherent to the iconoclastic current, as well as in the face of rigorous monasticism.

The death of Emperor Leo IV the Chazar (780) opened the perspective of the exit of the Constantinople Church from the iconoclastic crisis triggered by his grandfather, Emperor Leo III Isaurus or the Syrian (717-741) (Gero 1973:48). Empress Irina, co-regent with her minor son, Constantine VI (780-797) had to act very cautiously to restore the cult of icons. Patriarch Paul IV of Constantinople (780-784) had been confirmed by Emperor Leo IV, before whom he had taken an oath of allegiance, which also required respecting the iconoclastic decisions of the

Note: Special Collection: Lucian Blaga University, Sibiu, Romania, sub-edited by Daniel Buda (Lucian Blaga University) and Jerry Pillay (University of Pretoria). 
Synod of Hieria (754) and the army consisted of soldiers educated in the iconoclastic spirit by Emperor Constantine V (741-775). The brilliant victories against the Arabs and the Bulgarians carried by the soldiers under the emperor who eliminated the cult of icons raised him in their eyes as 'a demigod' (Ostrogorsky 1963:113). Besides, most of the Constantinople episcopate had iconoclastic beliefs. However, Empress Irina having Tarasios as her secretary managed things in such a way that she created the premises for a return to the cult of icons and thus for the resumption of canonical-liturgical ties with the Church of Rome and the Eastern Patriarchates.

Patriarch Paul IV, ill and rebuked by the conscience that he led the Constantinople Church under the iconoclastic terror, decided to retire from his chair. Empress Irina linked this withdrawal to the election of a successor and asked for a written and public motivation in connection with this act (Theophanes, Chronographia, AM 6276).

Using this occasion, the empress prepared the election of the successor to the patriarchal throne through a large popular assembly held in the Magnaura Palace and thus was elected Tarasios, ordained and enthroned on December 25, 784 (Beck 1980:D78).

\section{Patriarch Tarasios}

Even in the context of his election as patriarch, Tarasios showed his ability to manage church issues with diplomacy and authority, and to become the artisan of rehabilitating the cult of icons in the synod. Certainly, Empress Irina was behind this election, precisely to entrust Tarasios, with greater chances of success, the coordination of the future ecumenical synod. Empress Irina knew that she risked a lot in this election, but the success of this approach meant a great gain for the Church and the State. She knew that there was no patriarch amongst the laity until then, and this might have aroused not only the disapproval of the clergy and the monks of the Byzantium, but also of the pope. At the same time, however, she saw no other viable solution. The Byzantine episcopate was mostly iconoclastic or obedient to iconoclastic politics until the death of Leo IV. Therefore, no candidate amongst the clergy would have been approved or willing to eradicate iconoclasm. The proposal of a candidate from amongst the monks, the most targeted being the abbot Plato from the Saccudion monastery, would have meant being a rigid patriarch, intolerant towards the iconoclastic episcopate which might have conducted to the failure of the future synod by not participating or excluding the participation of these bishops (Lilie 1996:56).

The reception of patriarchal dignity had to be accepted, according to custom, by the Eastern Patriarchates, and even more so by the Church of Rome. The patriarch announced his election in an encyclical accompanied by a confession of faith, mentioning the conditions under which his election was made, and what motivated him to accept this dignity. His approach was accompanied by the imperial letter requesting the resumption of the Eucharistic communion with the new patriarch and cooperation with him to hold the synod intended to combat iconoclasm. Although Pope Adrian I (772-795) expressed dissatisfaction with the election of Tarasios amongst the laity motivated by the violation of canonical norms, he gave his consent conditional upon the restoration of the cult of icons. In front of the papal legates, the patriarch had to publicly condemn the iconoclastic synod of Hieria to enter into communion with the Church of Rome, as testifies the Papal Letter to Patriarch Tarasios ( $\mathrm{ACO}^{2}$ III.3, p.).

Faced with the indirect but punctual expression of the claim of papal primacy, Patriarch Tarasios again showed skill and diplomacy, asking the pope to send legates to attend the synod. Once communion with Rome and the Patriarchates of Alexandria, Antioch and Jerusalem was restored, Patriarch Tarasios could proceed to prepare for the convening of the synod, asking Empress Irina to send invitations. The Constantinople episcopate responded accordingly, with about 330 hierarchs participating in the synod. Pope Adrian I delegated Archbishop Peter and hieromonk Peter, abbot of the 'Saint Sava' Monastery in Rome, but did not appeal to other bishops, especially the Franks in the kingdom of Charlemagne (Nan 2005:127-141). From Alexandria came the hieromonk Thomas, and from Antioch the hieromonk John, both signing the acts of the synod as delegates of the apostolic Seats of the East, and therefore for Jerusalem also (Dumeige 1985:137). Even though Patriarch Theodore of Jerusalem, who had been exiled by the Arab authorities, could not send any representatives, he still managed to hand over to the hieromonks Thomas and John a synodal letter confirming the adherence of the Patriarchate of Jerusalem to honour the icons and condemn iconoclasm (Chifăr 1993:146-151).

Although they did not come with special mandates from the Eastern Patriarchates, the hieromonks Thomas and John behaved as patriarchal legates and the Synod recognised this quality, as they were signing the synodal acts to the positions corresponding to the diptychs, that is, after Patriarch Tarasios of Constantinople.

Inexplicable to his ability as a good organiser, Tarasios experienced the failure of its first attempt to hold the synod on August 7, 786 A.D. in the church of the 'Holy Apostles' in Constantinople. Relying on imperial authority and the support of the senate and dignitaries, the patriarch did not take into account the fact that most bishops had been followers of iconoclasm and the imperial military guard was educated in an iconoclastic spirit. The commotion and disorder caused by the soldiers entering the church whilst the abbot Plato of the Saccudion Monastery, entrusted by Patriarch Tarasios, gave a speech in favour of honouring the holy icons (Hefele 1877:457) could not be controlled by Empress Irina and the iconoclastic bishops taking advantage of this incident left the church rejoicing: we won! The works of the synod were stopped and the bishops returned to their dioceses. 
Better tactical preparation of the synod was left to the patriarch, who showed all his ability and diplomacy with the help of Empress Irina and the papal legates and the Eastern Patriarchates detained in Constantinople for a later convocation of the synod (Theophanes, Chronographia, AM 6279). Simulating an attack on the Arabs, he brought troops from Thrace in favour of the cult of icons, disbanded the old imperial guard and formed a new comprising European soldiers. Another invitation was sent to the bishops to attend a new synod convened this time in Nicaea.

\section{Patriarch Tarasios and the Nicene Synod}

On September 24, 787, the works of the VII Ecumenical Synod were opened in the church 'Saint Sophia' in Nicaea under the honorary presidency of the papal legates, but under the effective presidency of Patriarch Tarasios (Beck 1980:D79). From the way the synodal debates took place and the expected result was obtained, it can be seen that the 'clear mind' and 'authoritarian hand' of Patriarch Tarasios directed everything, required the approval of previously formulated documents and acceptance of the procedure established under papal and oriental legates in the year of thorough preparation of the synod (ACO ${ }^{2}$ III.3: 931-932).

To give the synod general representation, which in itself was not natural, the synod being an assembly of bishops, Patriarch Tarasios allowed, in addition to the participation of imperial dignitaries, the presence of a significant number of monks, fervent and steadfast defenders of the cult of icons, but with no right to vote. Although he knew that they formed the intransigent group on the rehabilitation of iconoclastic bishops, the patriarch, to ensure a consensus and give moral satisfaction to these iconoclastic fighters, allowed them to participate and even publicly manifest their position, basing his success on his peaceful attitude towards the iconoclasts on their legal exclusion from voting (Lilie 1996:65).

Before proceeding to the theological debates of the synod, Patriarch Tarasios wanted to assure the participants and thereby win their goodwill, that the imperial interference in decision-making is excluded, as happened at the iconoclastic synod at Hieria (Chifăr 2003:289-299) with many witnesses amongst the bishops present, and that the Church of Rome and the Eastern Patriarchates resumed communion with the Constantinople Church and gave their consent for the restoration of the cult of icons within the synod.

In this sense, after the opening of the works of the synod, on September 24, 787, the imperial letter 'Sacra' (ACO² III.1:5-7) was read by which the emperors declared that they did not want to exert any pressure on the bishops as was the case at Hieria and throughout the iconoclastic period (Boicu 2018:533-567; Sieben 1979:306-343) but they will submit to the teaching of faith of the synod. It is recalled that the withdrawal of Patriarch Paul and the election of Patriarch Tarasios motivated and conditioned the convening of an ecumenical synod on the issue of the cult of icons and bishops should campaign for the restoration of peace in the Church as requested by Pope Adrian I and Eastern patriarchs in letters, which were to be read in subsequent meetings.

In the second meeting of the synod (September 26, 787) the letters of Pope Adrian I to the emperors Constantine VI and his mother Irina and Patriarch Tarasios were read; letters brought by papal legates since 786 A.D. and known by the recipients. This detail is important to understand what agreements/compromises were made between the papal legates and Patriarch Tarasios regarding their content, especially regarding statements and conditions that could have compromised the patriarch's authority and implicitly the success of the synod. We are talking about the agreements that were made from the perspective of the failure of the synod of August 7, 786 in Constantinople and the thorough preparation of the future synod under the careful and direct coordination of Patriarch Tarasios. The very fact that the synod took place in eight sessions in an extremely short and unusual period for such an event (September 24-October 23, 787) denotes a thorough prior preparation whose craftsman was, as can be seen, Patriarch Tarasios.

In the letter to the sovereigns, the pope praised their zeal for preserving and spreading the true faith as preached by the Saint Apostle Peter to Romans and as preserved by his successors, including the veneration of the holy icons. The authority and primacy of St. Peter are particularly highlighted as a foundation for the increasingly obvious conception of the papal primacy. To diminish this claim, in the Greek translation of the letter read before the participants in the synod also appears the name of Saint Paul, which was certainly the intervention of Patriarch Tarasios $\left(\mathrm{ACO}^{2}\right.$ III 3.1: 127-128).

After the pope showed that the holy icons were honoured in the Church and that Emperor Leo III provoked the iconoclastic crisis that all his predecessors opposed since Pope Gregory II and which produced the division of the Church, he asked the emperors to restore the unity of the Orthodox faith in the Greek (Byzantine) lands under their rule. The holy icons have been honoured by all Christians since time immemorial and throughout the world (Buda 2016) because,

$[R]$ egarding the icons that represent the Son of God incarnate for us and our salvation, our souls are guided through His face towards spiritual love. In the same way, we worship this Saviour, Who is in heaven, and glorify Him, directing our souls to Him, as it is written, God is Spirit and therefore we worship His Godhead spiritually. (ACO² III.1:131-132; pp. 69-80)

The argument is accompanied by scriptural and patristic texts (ACO² III.1:132-153).

At the end of the letter, there is talk of the intention of the emperors to convene a synod, which was greeted with great joy by the pope. He is willing to send legates if the pseudosynod at Hieria will be anathematised, and by a 'Sacra' letter 
the emperors would give assurances that they would not exert pressure on the synod or its legates, but would allow the synod to decide freely. The pope also demanded that those provinces that formed Patrimonium Sancti Petri and were taken by Emperor Leo III be returned in full. Otherwise, the schism between Byzantium and Rome will not be lifted. He also emphasised the primacy of Rome. He is surprised that the emperors called Tarasios 'ecumenical patriarch' (Konidakis 1960:104) and demanded that in the future this title, which is against the Church Tradition, should no longer be used ( $\mathrm{ACO}^{2}$ III.1:156). Pope Adrian was outraged that Tarasios was elected patriarch from the laity. Therefore, he mentions that he will not recognise this election, 'if he (Tarasios) will not have a steady contribution to the restoration of the cult of icons' (ACO ${ }^{2}$ III.1:157-158).

It is observed that Anastasius Bibliothecarius, translating the acts of the synod states that the end of this letter is not included in the Greek version of the synodal acts. He found the original letter in Rome and put it in the right place (ACO ${ }^{2}$ III.1:152-160). This part of the letter is political in nature and focuses more on emperors. Because the pope rebuked the non-canonical election of Patriarch Tarasios, this could have motivated the opposing bishops to restore the cult of icons to disobey him, and thus the synod would again fail (ACO ${ }^{2}$ III.1:152-155). Some authors believe that the letter of Pope Adrian I was read in its entirety and only during the pastorate of Patriarch Photius was the abbreviated version introduced in the synodal acts (Wallach 1966:103-125). As the papal legates participated in the preparation of the synod and indeed understood that this paragraph could have caused the failure of the synod, it can be admitted that this part of the letter was not read and that this happened with the approval of the papal legates (Ostrogorsky 1933:75).

Pope Adrian I's letter to Patriarch Tarasios followed in response to his synodal encyclical (ACO ${ }^{2}$ III.1:168-179). The pope had no reservations about the orthodoxy of the patriarch's faith and accepted his encyclical, but expressed concern that Tarasios had become a patriarch from the laity. He did this on the condition that the patriarch campaigned for a synod at which the pseudo-synod at Hieria would be condemned and the cult of icons would be restored. He then reports on his decision to send legates to the synod and asks that they be received amicably. It does not avoid emphasising the primacy of Rome which has been entrusted to this Church by Christ the Saviour himself. If the patriarch wanted to keep in touch with the throne of Rome, then he must convince the emperors of the need to restore the cult of icons in both the capital and the whole empire. Otherwise, he cannot recognise Tarasios' election as patriarch.

After reading the letter, the papal legates asked Patriarch Tarasios if he agreed with what the pope had sent. He answered them 'elegantly', beginning with the praises that Saint Apostle Paul addressed to the Romans: 'Your faith is spoken of throughout the whole world' (Rm 1:8) and continued:
[W]e have known, we have confessed and we will continue to do so and we fully agree that we are in the same spirit of the letter that has just been read and we approve of the holy icons painted in colours according to the old Tradition of our Fathers. We honour them in a just understanding of worship, for they were made in the name of Christ the Saviour and of the everlasting Virgin, His Mother and in the name of the holy angels and all saints. But it is clear to us that our worship and our faith are directed first of all to the true God. ( $\mathrm{ACO}^{2}$ III.1:180-182)

As we can see, this response was based on a compromise, a tacit understanding between the patriarch and the papal legates. The end of Pope Adrian I's letter to the emperors was not mentioned because he considered Tarasios' election as patriarch being non-canonical. The letter to the patriarch, however, had to be read in its entirety, although the pope's dissatisfaction with the election of the patriarch from amongst the laity was also expressed there. We think it was the desire of the legates for things to happen that way. The fact that they were satisfied with the answer of Patriarch Tarasios, although it was not a very clear answer, shows that we are dealing with a compromise for the success of the synod. However, the legates did not want the rebuke of Pope Adrian to be known, at least formally, and that is why they insisted on the full exposition of the letter. But in order not to compromise Patriarch Tarasios, they tacitly agreed to his answer.

The whole synod approved these documents and the patriarchs responded with acclamations: 'So do we, the whole synod!' The legates then asked the synods to confirm both letters with their signatures. A total of 262 signatures were registered (ACO² III.1:185-219). Patriarch Tarasios also asked the monks to express their agreement, which was carried out (ACO² III.1:219-220).

The letters brought by the hieromonks John and Thomas from the Eastern patriarchs were read in the same atmosphere of collaboration for the restoration of the church unity. Patriarch Tarasios was interested in expressing the support of the Eastern patriarchs for the restoration of the cult of icons to show that he had fulfilled his mission to organise an ecumenical synod for this purpose and that his synodal encyclical, which was gladly received in the East and read before the participants at the synod ( $\mathrm{ACO}^{2}$ III.1:230-252), represents a testimony that the patriarchal seats in Alexandria, Antioch and Jerusalem received his election without reservation or conditioning. Tarasios' diplomacy to consolidate his position in front of Rome and the Constantinople episcopate was also highlighted. Therefore, he expressly asked the papal legates to confirm that the encyclical sent to the Orient and read then was identical to the one sent to Pope Adrian I (ACO² III.1:252-253).

Having confirmed from the papal legates that the teaching of faith contained in these letters concerning the veneration of holy icons is the same as that confessed by Pope Adrian I in his letter, the patriarch made a new gesture to assure the participants that he had fulfilled his mission: 
Disputes are over, the dividing wall of enmity between East and West, between North and South has been removed. We all walk together under the same yoke and the symphony has settled between us. (ACO² III.1:280)

The diplomacy, intelligence, firmness and organisational spirit of Patriarch Tarasios were especially highlighted in the procedure of repressing the former iconoclastic bishops in the communion of the Church. This issue was discussed in three sittings and required special attention.

Patriarch Tarasios was aware that most of the Constantinople episcopate was a real or formal follower of iconoclasm. The replacement of these bishops was not possible because, on the one hand, he did not have trained staff in this respect, and on the other it would have created the premises for the formation of an iconoclastic opposition difficult to manage, as witnessed at the first synodal attempt from August 7, 786. It would have been even more difficult to manage this phenomenon if he had raised it to the episcopal rank monks from the iconodules, intransigent on the rehabilitation of former iconoclastic bishops. In these conditions, Patriarch Tarasios analysed the situation very lucidly and, in agreement with the papal and oriental legates, witness to the actions of the coalition of iconoclastic soldiers-bishops in the summer of 786, provided a procedure for the repression of former iconoclasts in the communion of the Church. Ignoring some uncompromising positions on the part of the monks present at the synod, but making use of the fact that they did not have the right to vote, the patriarch skilfully and successfully led the discussions on the readmission of the iconoclasts. He did not make this a self-evident problem so as not to overfavour the bishops and injure the monks in their pride, imposing a procedure of general penance, but where it was specially imposed, he acted accordingly.

From the first meeting, some bishops were rehabilitated. The condition imposed on them was to renounce iconomachy, anathematising the decisions of the iconoclastic synod of Hieria and publicly submitting a confession of faith regarding the acceptance of the veneration of holy icons followed by a proper act of worshipping them if they were not guilty of other violations of church discipline and dogma, and regret towards their iconoclastic past (ACO ${ }^{2}$ III.1:40-52; 58-80). Relying on the fact that the bishops declared that they were born and educated in an iconoclastic spirit, Patriarch Tarasios emphasised that they became partakers of the heresy out of ignorance and by appealing to patristic texts he convinced the synod and especially the monks that their readmission was under the canonical norms and that the agreement given for the decisions at Hieria was not based on conviction, but on obedience to an imperial order (Dumeige 1985:143).

In the case of bishop Gregory of Neocaesarea, the patriarch was much categorical. Suspecting him of formalism and opportunism, he asked him to submit a written and signed confession of faith and postponed the readmission for a subsequent meeting. The procedure applied to the readmission of this bishop and others like him reveals the correctness combined with the church diplomacy manifested by Tarasios. The description of the whole debate is eloquent. In the third session, on September 28, 787 (ACO ${ }^{2}$ III.1:222-280), Gregory was again brought before the Episcopal Synod together with seven other brethren. After reading the required confession of faith, the question arose as to whether those who mistreated the iconodules could be received into the communion of the Church. According to the canonical norms (canon Apostolic 27 was quoted), such clerics must be defrocked. Sicilian bishops said that the Fourth Ecumenical Synod of Chalcedon deposed bishop Dioscorus of Alexandria because of the charge of murder. bishop Gregory of Neocaesarea, however, assured the synod that neither in his city of residence nor his diocese had he assaulted anyone. When abbot Sava of the Studion Monastery accused him that he had a dominant position in the Synod of Hieria, the argument was made between the participants that in Chalcedon the bishops present at the Robber Council (Ephesus, 449) were allowed. These debates thanked John, the imperial eunuch, for in this way the iconoclastic bishops were allowed to express their regret for their previous convictions. The moderate party won over the rigorous one, with Patriarch Tarasios thanking the monks for their vigilance and perseverance in defending truth and justice. Bishop Gregory of Neocaesarea along with seven other bishops was rehabilitated, promising to return to the episcopal see. Most likely, as an act of penance, bishop Gregory had to read, in the sixth session of the synod, the judgement of Hieria and listen to its rejection and condemnation (Speck 1978:176).

By reading and approving the papal letters and those sent from the East and by rehabilitating a majority of the former iconoclastic bishops, peace was restored in the Church, an essential requirement for the continuation of the work of the synod. The achievement of ecclesiastical unity in less than a week was largely because of Patriarch Tarasios, who attached great importance to the preparation of the synod and managed the tense moments successfully satisfying the wishes of both papal legates and scrupulous monks and the Constantinople episcopate that agreed with the iconoclasm. Whilst the papal legates sought to emphasise, according to the instructions received from Pope Adrian I, that the unity of the Church is ensured by the papal primacy ('a flock and a shepherd', cf. Jn 10:16), and the Eastern Churches pleaded for the unity between the 'priesthood and empire' as the foundation of church unity, Patriarch Tarasios, without denying the importance of the State-Church symphony, wrote to the Constantinople clergy that the unity of the Church was achieved through Christ. He is its head, he is the head of the synod and his visible presence is marked by the Holy Gospel placed on the throne. This time also the patriarch wanted to prioritise his point of view.

Another moment of good coordination and direction of the work of the synod by Tarasios was consumed during the fourth and fifth meetings (ACO ${ }^{2}$ III.2:280-530; 532-598) when the scriptural, patristic and traditional arguments in favour of the veneration of the holy icons were exposed. This time, the patriarch gave great satisfaction to the monks 
by allowing them to speak and contribute to their expositions to the foundation of the cult of icons. The atmosphere was so favourable that Tarasios was able at the end of the fourth session, after the letters of Pope Gregory II (715-731) to Patriarch German of Constantinople (715-730) (ACO ${ }^{2}$ III.2:450-452) and of German to the bishops John of Synnada, Constantine of Nakoleia and Thomas of Klaudiopolis ( $\mathrm{ACO}^{2}$ III.2:452-478) were read, to entrust bishop Euthymius of Sardis to expose the synodal confession of faith regarding the veneration of the holy icons, confirmed by the signatures of 465 participants, including priests and monks even without the right to vote. It was also the work of Patriarch Tarasios, who thus obtained general support for the synod's debates on iconoclastic heresy. It was not a final decision, a synodal dogmatic definition, so he allowed himself to do so and give satisfaction to priests and monks that they participated in the fight against iconoclasm.

We emphasise another crucial moment in the conduct of the synod because of Patriarch Tarasios. He considered necessary a punctual and detailed rejection of the dogmatic decision of the iconoclastic Synod of Hieria. Thus, in the sixth meeting of October 5, 787, this definition was read paragraph by paragraph (Nazâru \& Teodor 2008:195-235), which was punctually opposed by the iconophile position (Chifăr 1993:164-201). This theological struggle against iconoclasm is one of the most important pieces of the Seventh Ecumenical Council, whose author is considered to be Patriarch Tarasios (Alexander 1958:13). Therefore, he asked for this to be performed, and those present, even if they were simple listeners, were able to identify at one point or another their position and argument in favour of the cult of icons (Dumeige 1985:176).

The fact that Patriarch Tarasios was the organiser and the main mentor of the Nicene Synod also results from the fact that he considered himself entitled to inform the emperors $\left(\mathrm{ACO}^{2}\right.$ III.3:858-866), the Constantinople clergy ( $\mathrm{ACO}^{2}$ III.3:870-876) and Pope Adrian I (ACO ${ }^{2}$ III.3:926-930) about the decisions of the synod, dogmatic and canonical decisions approved in the penultimate session of the synod, that is the seventh meeting of October 3, $787\left(\mathrm{ACO}^{2}\right.$ III.3:794-856).

\section{Conclusions}

From the analysis made on the development and results of the VII Ecumenical Synod of Nicaea (787), it can be concluded that Patriarch Tarasios of Constantinople was the craftsman of this synod. The conclusion is based on the fact that compared with the first attempt to hold an ecumenical synod on the issue of icons that failed miserably, the Nicene Synod that took place after a year was a success in all respects. This can only be explained by careful and thorough training performed by a very wellcoordinated group. This group/commission was formed by the papal legates and those of the Eastern Patriarchates detained by Empress Irina in Constantinople after the failure from 786, having as mentor Patriarch Tarasios. The experience gained as imperial secretary and theological erudition allowed Tarasios to prepare and manage with authority, tact and church diplomacy the works of the synod to achieve the goal - to restore church unity and combat iconoclasm.

Through this, Patriarch Tarasios sought to assure Pope Adrian I through the statement made by his legates, eyewitnesses to the conduct of the synod, that he fulfilled his mission to rehabilitate the cult of icons, that he respected the conditions required by Rome and that the Patriarchate of Constantinople preserves its dignity and authority right in front of the Roman throne. The way he handled things, if it had been followed during the dispute between Pope Nicholas I and Patriarch Photius, would not have created the tension that was the premise of the Schism of 1054. The church diplomacy used by Tarasios was lacking in the approaches of Patriarch Photius, and the openness to the correct understanding of the context by Pope Adrian I no longer existed in the conditions of arrogance and primal impulse manifested by Pope Nicholas I. The aim of this study is not to demonstrate that Tarasios coordinated the Seventh Ecumenical Council but to show that the ecclesiastical diplomacy used by him in the conduct of the Synod, won the agreement and recognition of Pope Adrian I and maintained the dogmatic and canonical connection between Rome and Constantinople. It was the last major moment of theological and ecclesiastical collaboration between these two centres of Christendom.

As a final conclusion, in the present study we have tried to emphasise the fact that as a result of the diplomacy adopted by Patriarch Tarasios, recognition was obtained from Rome both for the canonicity of his election and for the conduct of the Nicene Synod, whilst in another similar context when other great personages acted with pride and arrogance, the dispute led to the schism between Patriarch Photius and Pope Nicholas I.

\section{Acknowledgements Competing interests}

The author declares that he has no financial or personal relationships that may have inappropriately influenced him in writing this article.

\section{Author's contributions}

C.N. is the sole author of this article.

\section{Ethical considerations}

This article followed all ethical standards for research without direct contact with human or animal subjects.

\section{Funding information}

This research received no specific grant from any funding agency in the public, commercial, or not-for-profit sectors. 


\section{Data availability}

Data sharing is not applicable to this article as no new data were created or analysed in this study.

\section{Disclaimer}

The views and opinions expressed in this article are those of the author and do not necessarily reflect the official policy or position of any affiliated agency of the author.

\section{References}

Alexander, P.J., 1958, Patriarch Nicephorus of Constantino ple. Ecclesiastical policy and image worship in the Byzantine Empire, Clarendon Press, Oxford.

Beck, H.G., 1980, Geschichte der orthodoxen Kirche im byzantinischen Reich, Vandenhoeck \& Ruprecht, Göttingen.

Boicu, D., 2018, 'De pe revers pe avers și viceversa. O recontextualizare a reprezentărilor numismatice ale Mântuitorului în Bizanț', in A. Pavel (ed.), Voi pune înainte lerusalimul ca început al bucuriei mele. In honorem Pr. Prof. Univ. Dr. Dumitru Abrudan la împlinirea vârstei de 80 de ani, pp. 533-567, Astra Museum, Sibiu.

Buda, D., 2016, 'The power of image in two writings of Theodoret of Cyr', in J.A. McGuckin (ed.), Orthodox and the Sacred Arts, pp. 69-80, Theotokos Press Sophia Institut, s.l.
Chifăr, N., 1993, Das VII. ökumenische Konzil von Nikaia, Erlangen.

Chifăr, N., 2003, 'Teologia iconoclastă a împăratului Constantin al V-lea și Sinodul de la Hieria (754)', in Studia Historica et Theologica. Omagiu profesorului Emilian Popescu, pp. 289-299, Trinitas Publishing, s.l.

Dumeige, G., 1985, Nizäa II, Grünewald, Mainz.

Gero, S., 1973, Byzantine Iconoclasm during the Reign of Leo III, Peeters Publishers, Louvain.

Hefele, C.J., 1877, Konziliengeschichte, Bd. III, Freiburg im Breisgau.

Konidakis, G., 1960, Weltkirchenlexikon, hsg. von F.H. Littell \& H.H. Walz, Stuttgart.

Lilie, R.J., 1996, Byzanz unter Eirene und Konstantin VI. (780-802), Berliner Byzantinische Studien, Bd. 2, Peter Lang Verlag, Frankfurt am Main.

Nan, A.D., 2004, 'Sinodul de la Frankfurt (794)', Revista Teologică 4(2004), 114-121. https://doi.org/10.18356/64636398-es

Nan, A.D., 2005, 'Efectul iconoclasmului bizantin asupra papalităţii şi a regatului franc', Revista Teologică 4(2005), 127-141.

Nazâru, S. \& Teodor, I., 2008, 'Hotărârea sinodală de la Hiereia (754) - summa gândirii iconoclaste. Prezentare și traducere', Studii Teologice 4, 127-141.

Ostrogorsky, G., 1933, 'Rom und Byzanz im Kampf um die Bilderverehrung', Seminarium Kondakovianum 6, Prague.

Ostrogorsky, G., 1963, Geschichte des byzantinischen Staates, C.H. Beck, München.

Sieben, H.J., 1979, Die Konzilsidee der Alten Kirche, Schöningh. Paderborn.

Speck, P., 1978, Kaiser Konstantin VI., volumes I-II, Fink, München.

Wallach, L., 1966, 'Greek and Latin Version of Nicaea II and the Synodica of Hadrian I', Traditio 22(1966), 103-125. https://doi.org/10.1017/S0362152900010680 